Anuario de Estudios Medievales

41/2, julio-diciembre de 2011

pp. 673-698

ISSN 0066-5061

\title{
OBREROS, MONEDEROS Y CASAS DE MONEDA. REINO DE CASTILLA, SIGLOS XIII-XV
}

\author{
MINT-WORKERS, MONEYERS AND MINTS. \\ KINGDOM OF CASTILE, $13^{\text {th }}-15^{\text {th }}$ CENTURIES
}

\author{
JULIO TORRES \\ Museo Casa de la Moneda, Madrid
}

\begin{abstract}
Resumen: En este trabajo se describe la fabricación de la moneda en la Edad Media, desde la recepción de los metales hasta la entrega del producto acabado. También se mencionan las diferentes casas de moneda medievales y su organización empresarial y técnica, así como las funciones de los operarios y los principales oficiales.
\end{abstract}

Palabras clave: casas de moneda; fabricación de moneda.

\begin{abstract}
In this paper the minting process in the Middle Ages, from receipt of the metals to delivery of the finished product, is described. The various mediaeval mints and their corporate and technical organization are also discussed, in addition to the functions of the workers and the leading officials.
\end{abstract}

Keywords: mints; minting coinage.

\section{SUMARIO}

1. La casa de la moneda.- 1.1. Las casas de moneda.- 1.2. Régimen institucional.- 2. La fabricación.- 2.1. Antes de los obreros.- 2.2. Los obreros.- 2.3. Los monederos.- 3. Sistemas de control.- 3.1. Ensaye.- 3.2. Levadas.- 3.3. Control de aspecto.- 3.4. Libranza de la moneda.4. Ilustraciones.- 5. Apéndices.- 6. Bibliografía citada.

La acuñación de la moneda en la Edad Media ${ }^{1}$ se realizaba, en términos

${ }^{1}$ Los principales textos documentales en castellano acerca de la fabricación de la moneda en la Edad Media fueron editados y estudiados, partiendo de los manuscritos, en mi tesis doctoral, J. Torres, Ordenanzas medievales. Para no complicar en exceso esta publicación, me referiré a estos textos, siempre que sea posible, remitiendo a la paginación de mi tesis, fácilmente accesible en internet, pero, para quien quiera profundizar, las relaciono en el Apéndice 5.1., por orden cronológico, mediante abreviaturas compuestas por el nombre de la ciudad en que se promulgaron (en cursiva) seguido de la fecha, con indicación de la fuente utilizada y otras ediciones impresas anteriores a la mía. En el ámbito castellano, aparte de las ordenanzas, solo es relevante como documentación primaria, aunque muy centrado en el tratamiento de los metales, el texto publicado y estudiado en B. Caunedo, R. Córdoba, El arte, al que me referiré como Alguarismo cuando haga referencia al texto editado. El resto de las referencias documentales las haré también remitiendo a la bibliografía que las edita o comenta. Las obras generales que estudian la fabricación de la moneda en la Edad Media, en castellano, son, por orden cronológico: F. Mateu y Llopis, La técnica, pp. 69-74; J. Torres, La fabricación, pp. 169-202; J. Torres, Monederos, pp. 301-326; y R. Córdoba, Ciencia. Los textos publicados en la revista "Numisma" hasta el número 244 (2000) pueden consultarse en http://www. 
generales, de la misma manera que en la Edad Antigua y como se seguiría realizando hasta bien entrada la Edad Moderna, por el procedimiento que hoy día denominamos acuñación a martillo. El método de la acuñación, empleado entonces y ahora, es, de entre las manufacturas que han perdurado hasta hoy, una de las más antiguas, pues las primeras monedas acuñadas conocidas se datan en algún momento del siglo VII a.C., o, siendo más cautos, en el VI. Simplificando, se suele decir que la moneda se ha acuñado a golpe de martillo hasta los siglos XVI o XVII y que a partir de esas fechas se fue introduciendo la maquinaria con gran lentitud, pues la tecnología disponible no era vista con buenos ojos por los trabajadores y no siempre estaba en condiciones de satisfacer las prescripciones técnicas (peso y ley) ni la velocidad de fabricación que este producto requería. Una vez mecanizados algunos de los procesos, los no mecanizados continuaron ejerciéndose de un modo tradicional, experimentando lentamente la lógica evolución que imponen los tiempos hasta los siglos XIX y XX en que todas las actividades industriales van adquiriendo su apariencia actual. Para saber cómo se fabricaban las monedas en la Antigüedad hay que recurrir a la Arqueología, a la Filología y al estudio de las propias monedas, pues no se conservan textos técnicos que puedan darnos una idea del proceso completo ${ }^{2}$. Tampoco conocemos cómo se producía en la Antigüedad la transmisión de los conocimientos técnicos de unas generaciones a otras y de unos pueblos a otros. Una buena parte, si no la totalidad, del arte de fabricar la moneda se inscribía en el arte de obtener y trabajar los metales, y estas artes se transmitirían de modo semioculto, pues su conocimiento era fuente de poder.

En los momentos y civilizaciones en que la necesidad de monedas acuñadas fue mayor, una gran cantidad de personas tenían que intervenir en su fabricación, lo que, en cierta manera, obstaculizaba, aunque no impedía, el mantenimiento de esos conocimientos dentro de un círculo restringido. La transformación en Europa del sistema imperial romano centralizado en otro multicéntrico significó un cambio en la organización de la fabricación de moneda. Por un lado, una sociedad más ruralizada tenía una menor necesidad de moneda, por otro, los nacientes centros de autoridad eran mucho menos ricos que el antiguo poder imperial. Los grandes talleres tendrían que disminuir sus efectivos, pero la multiplicación de centros de poder traería consigo una multiplicación de centros de acuñación. En algún momento, los trabajadores residuales de los antiguos talleres romanos junto con, quizá, elementos inmigrados desde el Imperio Bizantino, pusieron el germen de una organización europea de fabricantes de moneda y, probablemente, se repartieron el naciente mercado ${ }^{3}$.

Unas inscripciones encontradas en Roma, relacionadas con una de sus casas de moneda, nos informan de algunos de los nombres de los diversos oficios que en ella se ejercían ${ }^{4}$. Aunque no esté del todo claro a qué se dedicaba cada uno de ellos,

fnmt.es/index.php?cha=siaen\&scha=26\&page=126 o en www.siaen.org. El estudio de G. Céspedes, Las cecas, vol. I, aunque dedicado a la época moderna, es excelente, y aplicable en un gran porcentaje al medievo. Basado en documentación francesa, el capítulo 10 (La fabrication monétaire) de M. Bompaire, F. Dumas, Numismatique, pp. 453 y ss. Como novedad bibliográfica de gran interés, ha aparecido recientemente una tesis doctoral leída en Francia que complementa el estudio de algunas fuentes de época y de ciertas evidencias arqueológicas con la experimentación actual en el laboratorio o en el taller: A. Arles, Entre monnayage.

${ }^{2}$ Sobre fabricación de moneda en la Antigüedad: T. Hackens, Terminologie, pp. 1-15; M.P. GarcíaBellido, Problemas técnicos, pp. 9-50; M. Gozalbes, P.P. Ripollès, La fabricación, pp. 11-33.

${ }^{3}$ R.S. Lopez se ocupó de estudiar la evolución del oficio de la moneda desde la Edad Antigua a la Moderna: R.S. Lopez, Continuità, II, pp. 74-117 y R.S. Lopez, I monetieri (es traducción del original en inglés, publicado en 1953). Ambos trabajos incluidos en la recopilación The shape of medieval monetary history, capítulos III y IV respectivamente.

${ }^{4}$ Véase J. Torres, Las cecas, pp. 131-152 y J. Torres, Moneta Caesaris, pp. 89-103. 
es evidente que el trabajo estaba ya dividido de una forma muy similar a como lo ha estado posteriormente.

El paso de la península ibérica de la zona de civilización romano-cristiana a la de civilización árabe-musulmana trajo consigo los métodos de fabricación de la moneda que el califato inicial había importado a su vez de los imperios Bizantino y Sasánida. Las diferencias con los métodos empleados en la Europa poscarolingia son pequeñas si no se pretende profundizar, aunque el tipo de moneda fabricada en una y otra áreas es bastante diferente, de acuerdo con el tipo de economía vigente en cada una de ellas. En este trabajo, partiendo, como ya he dicho, de la documentación medieval castellana, me ocuparé principalmente de la tradición europea ${ }^{5}$. Los incipientes estados cristianos que se fueron creando en el norte de la península funcionaron sin moneda propia hasta bien avanzada la Edad Media, no obstante, los Pirineos fueron permeables a la entrada de monedas europeas, mientras que la moneda acuñada en el sur no tendría otro inconveniente para circular que la existencia o no en cada momento de intercambios comerciales o de las cuotas periódicas del seguro de paz conocido como parias. Por motivos que ignoramos, en el momento en que los estados cristianos deciden acuñar su propia moneda, tanto los condados catalanes como el resto de reinos utilizan las técnicas ya asentadas en otros territorios europeos en lugar de dar continuidad a los talleres que encontraron en las ciudades musulmanas ocupadas 6 .

Desde los primeros textos escritos medievales que podemos considerar técnicos, aunque se encuentren insertos en textos legales, aparece la clara distinción entre obreros y monederos dentro del personal de la Casa de Moneda ${ }^{7}$. Como veremos más adelante, cada uno de estos dos colectivos se dedicaba a una fase del proceso de fabricación, cuyo resultado final era, respectivamente, la obra y la moneda. Se denominaba también monederos, como genérico, a todos los trabajadores de la Casa de Moneda, incluyendo también a los obreros. Pero nunca se denomina obreros, como quizá haríamos hoy, a todos los trabajadores de la fábrica. Este colectivo, que se reunía en asociaciones territoriales y asambleas de fábrica, gozaba de unos privilegios, leyes particulares que inicialmente habían sido normas coercitivas para obligarles a permanecer en sus puestos ${ }^{8}$ y terminaron convirtiéndose en privilegios en el sentido moderno, en pesadas losas que, ya en vísperas de la Edad Contemporánea, lastraban la modernización del ramo.

En 1497, la Pragmática de Medina del Campo (Medina 1497) culminaba dos siglos de ordenación de la fabricación de la moneda durante la Edad Media castellana y ponía las bases de lo que iba a ser dicha fabricación durante otros dos siglos. En el análisis de este texto y de los que le precedieron se fundamenta buena parte de

5 Para la fabricación de moneda islámica, véase: A.S. Ehrenkreutz, Extracts, pp. 423-447; A.S. Ehrenkreutz, Contributions, pp. 502-514 (los dos trabajos de Ehrenkreutz incluidos en la recopilación A.S. Ehrenkreutz, Monetary Change); C. Toll, Minting technique, pp. 125-139; C. Cahen, La frappe, pp. 335-338; K. Ben Romdhane, Traité inédit, pp. 207-226; C. Toll, The fabrication, pp. 331-333; F. Barrage, Chapter five. "As-Sikka: The on line Journal of the Islamic Coins Group" 3/1 (2001) (www.islamiccoinsgroup.50g.com/assikka31/Dawabit.htm, página web desaparecida en noviembre 2011). Existe una versión impresa publicada en España en árabe por el Instituto de Estudios Islámicos en 1960, en edición crítica de Husayn Mu'nis (Abu-l-Hasan Ali Ibn Yusuf Al-Hakim, Al-dawha al-mustabika).

6 J. Torres, Primeros, pp. 551-557.

${ }^{7}$ Siempre que no se indique lo contrario, hablaremos del ámbito de la lengua castellana medieval, estudiado en J. Torres, Ordenanzas medievales. Sobre la denominación de las Casas de Moneda en latín y en otras lenguas véase J. Torres, Las cecas, p. 132 y J. Torres, Moneta Caesaris, p. 90.

${ }^{8}$ J. Torres, Acuñación, pp. 214-223 (en p. 215-216). 
los conocimientos que tenemos en la actualidad acerca del proceso de fabricación de la moneda en la Edad Media9.

\section{LA CASA DE LA MONEDA}

Los estudiosos de la numismática en lengua española se suelen referir a las fábricas de moneda con el nombre de cecas, apelativo que ha resultado especialmente útil para la numismática antigua, dado que es un nombre corto que evita tener que referirse repetidamente a casas de moneda o talleres monetarios. Además, en numismática antigua el término se utiliza también, aunque de un modo vago, para designar a las ciudades que acuñaron moneda o al conjunto de la producción monetaria de una ciudad. A pesar de que se reconoce su ascendencia árabe, la introducción de este término en la lengua castellana es relativamente reciente, y quizá más que un cultismo tomado directamente del árabe sea un préstamo del catalán seca, que aparece en los diccionarios académicos desde el de Autoridades, en tanto que la pronunciación castellana, ceca, no está atestiguada hasta el diccionario de $1843^{10}$. La documentación medieval (y la moderna) castellana habla siempre de casa de moneda.

Dependiendo del momento y del lugar, la casa de moneda puede ser, desde un pequeño taller, a veces ambulante o improvisado, hasta un edificio complejo, o incluso un conjunto de edificios, en los que llegaba a trabajar una gran cantidad de personas ${ }^{11}$. Sin embargo, la célula básica era siempre la misma: una fundición de metales, que en ocasiones no se encontraba en el mismo edificio, y dos conjuntos de talleres, uno de fabricación de cospeles ${ }^{12}$ y otro de acuñación. Mientras que el taller de acuñación estaba integrado por acuñadores individuales en la cantidad necesaria, la producción de cospeles estaba organizada a su vez en pequeños talleres compuestos por equipos de cuatro o cinco personas al mando de un capataz, denominados horna$z a s^{13}$. La cantidad de hornazas de cada casa marcaba su capacidad productiva, que se indicaba por hornaza y día.

Además de los talleres de fabricación, la casa contaba, o podía contar, con otros departamentos técnicos, como el laboratorio de ensayes o el taller de grabado de cuños, y otros administrativos, como la tesorería. Cuando la estructura de la institución lo aconsejó y su tamaño lo permitió, algunos de los principales oficiales de la casa tenían vivienda dentro del propio recinto ${ }^{14}$.

\subsection{Las casas de moneda}

En el momento de la promulgación de la Pragmática de Medina del Campo había teóricamente siete casas de moneda en el territorio de la corona de Castilla ${ }^{15}$.

\footnotetext{
${ }^{9}$ Los textos de las ordenanzas, relacionadas en la Bibliografía final, desde Lorca 1297 a Medina 1497, en J. Torres, Ordenanzas, pp. 48-201.

${ }_{10}$ J. Torres, España. Cecas, pp. 287-296 (en p. 288). Para el origen del término italiano zecca, directamente relacionado con el catalán seca, véase L. Travaini, Zecca, vol. XI, pp. 844-847.

${ }^{11}$ J. Torres, La fabricación, pp. 197-198; J. Torres, Acuñación, pp. 217-218.

${ }^{12} \mathrm{El}$ cospel es el disco metálico que, una vez acuñado, se convierte en una moneda.

${ }^{13}$ Véase “4.1.2.2 Hornaza” y “4.2.4.5 Capataz”, en J. Torres, Ordenanzas, pp. 402-414 y 456-459.

${ }_{14}$ Sobre los diferentes espacios relacionados con la casa de la moneda, J. Torres, Ordenanzas, pp. 391-417; R. Córdoba, Ciencia, pp. 72-80.

15 Sobre la historia de estas casas de moneda, véase J. Torres, España. Cecas, y J. Torres, Las casas, pp. 299-330 y la bibliografía citada en ambos trabajos. Un mapa de las casas de moneda cas-
} 
Seis de ellas eran más o menos tradicionales, ya que se habían ido fundando a lo largo de la Edad Media: La Coruña, Burgos, Cuenca, Toledo, Segovia y Sevilla. La séptima se había fundado en Granada a raíz de la conquista del reino nazarí, y, por tanto, debemos considerar que sus acuñaciones cristianas pertenecen a la Edad Moderna. Durante la Edad Media existieron otras casas de moneda menores en otras ciudades, $\mathrm{e}$, incluso, es bastante probable que, al menos en algunos periodos, hubiera una ceca móvil que viajaba con la Corte. La historia de todas estas casas durante la Edad Media está prácticamente sin hacer. Para ello habría que recurrir a los archivos municipales (sabemos que el de Cuenca alberga alguna documentación) y a unos pocos legajos del siglo XV del Archivo de Simancas que han sobrevivido a la invasión napoleónica. Con todo y con eso, la parte comprendida entre los siglos XII y XIII (en Castilla, León y Portugal no se acuñó moneda propia hasta finales del siglo XI) quizá haya que buscarla en archivos eclesiásticos, dado que la mayoría de las ciudades en las que se piensa o se sabe que se acuñó moneda eran sedes episcopales.

Otra fuente de documentación para conocer en qué ciudades se acuñó moneda son las propias monedas. Las primeras acuñaciones mencionan a León y Toledo, pero eso no es indicativo de que fueran acuñadas en esas ciudades, sino de que se acuñaban para circular en esos reinos. Los nombres de ciudades en esta primera época deben ser tomados como indicio de concesiones de acuñación, o de parte de sus beneficios, a algunas sedes episcopales. La mención del reino de Castilla no aparece hasta la división de los reinos, durante el reinado de Alfonso VIII ${ }^{16}$.

De las casas tradicionales, la considerada como más antigua es la de Toledo, para la cual disponemos de una fecha post quem, 1085, la de la toma de esta ciudad por las tropas de Alfonso VI, que se suele tomar como inicio de las acuñaciones castellano-leonesas, aunque puede que se iniciaran antes en otras ciudades como Santiago de Compostela o León, y también es posible que la ceca cristiana de Toledo no empezase a funcionar ese mismo año. La casa de la moneda de León, si realmente existió, tuvo una vida efímera, no ha dejado apenas rastro documental y no se cuenta entre las seis tradicionales. La de Burgos no empieza a trabajar antes de mediados del siglo XII, y su producción en el siglo XV se equiparaba a la de Toledo. Las de Cuenca y Segovia se abrieron en los momentos respectivos de su conquista, recibiendo la segunda un impulso durante el reinado de Enrique IV, que apreciaba mucho aquella ciudad. La de La Coruña podría haber iniciado su andadura a principios del siglo XIII, convirtiendo desde entonces en esporádicas las acuñaciones en Santiago y Lugo. Por último, la casa de la moneda de Sevilla podría haber comenzado a acuñar con Fernando III y es seguro que lo hizo con Alfonso X. Fue la fábrica de moneda más importante hasta la llegada de la dinastía borbónica en el siglo XVIII, especialmente cuando comenzó a hacerse cargo de la mayor parte de los metales preciosos que llegaban a su puerto desde América sin acuñar. De los talleres secundarios, quizá el más importante fuera el de Valladolid, del que se conserva bastante documentación del siglo XV.

tellanas en el siglo XV en A. MacKay, Moneda, p. 45, con indicación de la capacidad productiva de algunas de ellas, de acuerdo con la cantidad de hornazas, que el traductor ha traducido como hornos, a pesar de que el documento número 1 del apéndice, en el que se basa esa información, habla claramente de fornazas.

${ }^{16}$ Sobre la moneda castellano-leonesa hasta la llegada de la dinastía Trastámara, véase A. Roma, Moneda y sistemas; A. Roma, Emisiones. Para la dinastía Trastámara: A. Roma Valdés, J.L. Braña, El vellón. Para un enfoque más general de la moneda dentro del contexto económico y financiero de su época, véanse los trabajos de M.A. Ladero, en especial: La política, pp. 79-123; Monedas y políticas, pp. 129-178; y sus libros Fiscalidad y poder real y la reciente nueva edición ampliada de su La Hacienda Real. Véase también A. MacKay, Moneda. 
En la Corona de Aragón las principales casas de moneda medievales fueron las de Barcelona, Perpignan, Valencia y Mallorca. Aunque la más importante fue la de Barcelona ${ }^{17}$, quizá la más estudiada desde el punto de vista documental sea la de Valencia, que fue objeto de varios estudios por parte de Mateu y Llopis ${ }^{18}$.

\subsection{Régimen institucional}

El estudio institucional de la fabricación de la moneda abarca desde la legislación pertinente hasta la organización del taller, pasando por las asociaciones de trabajadores y sus privilegios ${ }^{19}$.

Los talleres de acuñación de moneda durante la Edad Media no eran fábricas montadas por el poder real, aunque todos los monarcas se arrogaban el derecho exclusivo de acuñar monedas en sus territorios ${ }^{20}$. Esta fabricación era tratada como un servicio o una renta que, como otras, se arrendaban a particulares a cambio de una compensación económica. A juzgar por los textos de las ordenanzas castellanas, las sumas recibidas en concepto de arrendamiento se generaban como porcentajes sobre la producción. Tratándose de una regalía de gran importancia económica, el monarca nombraba a determinadas personas para que ejerciesen en su nombre el control del correcto cumplimiento de lo ordenado.

La documentación castellana habla de los arrendadores de un modo muy vago, que no nos permite saber si se trataba, como suponemos, de los mismos maestros de moneda que eran a la vez técnicos en el tratamiento de metales y empresarios con capacidad de riesgo. R. Córdoba subraya además la capacidad de los mercaderes bajomedievales para manejarse en el mundo de la aritmética, lo que los hacía idóneos para resolver, por ejemplo, problemas de aleaciones complejas que, quizá, los maestros de moneda, en caso de ser personas diferentes, resolvían de un modo más empírico. Probablemente fue así inicialmente, y se arrendaba cada campaña de acuñación para una emisión determinada, como está documentado en otros lugares de Europa ${ }^{21}$, pero más tarde los arrendadores fueron ricos mercaderes y quizá, a finales del periodo

17 Recientemente se ha publicado una monografía sobre esta casa que dedica algunas páginas al taller medieval: M.E. Ripoll, La Seca; A. Estrada-Rius, La ceca, pp. 269-274, se ha ocupado de aspectos institucionales de este taller.

${ }^{18}$ Cito algunos de los trabajos de F. Mateu y Llopis sobre el particular: Ensayo sobre; El vocabulari, pp. 98-126; Libre dels privilegis; Acerca de la política; Notas y documentos, tomo II, vol. II, 1970, pp. 179-195 (apéndice documental).

${ }^{19}$ Los textos legislativos castellanos en J. Torres, Ordenanzas medievales, pp. 48-201. Un estudio de la legislación castellana y aragonesa fue realizado por J. Lluis y Navas en varios artículos: Aspectos de la organización legal, pp. 9-80; Los orígenes del derecho, pp. 27-99; La ordenación de la amonedación, pp. 25-99; La ordenación de la amonedación, pp. 59-199; La ordenación de la amonedación, pp. 9-160. Sobre la organización de las casas de moneda y las corporaciones de sus trabajadores, véase J. Torres, La fabricación, 2002, pp. 173-179 y los trabajos de A. Estrada-Rius, La ceca real, pp. 445-462; El capítol, pp. 77-94; Alcaldes de la Seca, vol. I, pp. 583-594; Els col-legis, pp. 71-79. J.A. García Luján, Privilegios de los monederos, pp. 541-555, aunque trata de un documento de 1515, integra las confirmaciones de los privilegios desde el reinado de Enrique II. Para el caso portugués el bien documentado D. Peres, História dos moedeiros, 2 vol., Lisboa 1964-1965. Para Francia, véase M. Bompaire, F. Dumas, Numismatique, pp. 383-451.

${ }^{20}$ Sobre el modelo empresarial de la acuñación de moneda, J. Torres, La fabricación, pp. 173 y ss.; R. Córdoba, Ciencia y técnica, pp. 81-90.

${ }^{21}$ Sobre la organización de la fabricación de moneda en la Edad Media en otros países europeos se ha escrito bastante. Fue pionero el volumen colectivo N.J. Mayhew, P. Spufford, Later Medieval, y todos los artículos recopilados en él. Sobre el ámbito francés véase M. Bompaire, F. Dumas, Numismatique, pp. 453 y ss., y en concreto sobre Borgoña, F. Dumas-Dubourg, Le monnayage, pp. 82 y ss. Sobre 
medieval, personajes notables de la corte que tomaban a su vez la fabricación de moneda como una renta para sí mismos, lo que se generalizaría en los siglos XVI y XVII.

En los primeros tiempos sería más correcto hablar de fabricantes de moneda que de fábricas de moneda, pues eran aquellos los que se desplazaban en busca de contratos, y la casa de moneda no tenía por lo general un edificio fijo, aunque una vez utilizado uno en concreto podía volver a utilizarse posteriormente con el mismo fin. En la segunda etapa, a partir del siglo XIII, en que empieza a haber indicios de que los edificios son ya más o menos estables, seguía sin ser la fabricación una actividad constante. Independientemente de que los sucesivos contratos los siguiese ganando el mismo empresario o que incluso dejase de haber subastas para cada campaña y el arrendador, o el tesorero de cada fábrica tuviese un compromiso a largo plazo, la fabricación se seguía realizando por campañas, respondiendo a dos criterios, la necesidad de moneda y la disponibilidad de metales, teniendo en cuenta que, por grande que fuese la primera, no se podría acuñar si la segunda era escasa. Entre campaña y campaña las fábricas se desmontaban completamente si el edificio tenía que ser desalojado, y si no, podían permanecer en él los instrumentos, pero el personal quedaba cesante hasta la próxima ocasión ${ }^{22}$. Consta que algunos o muchos de los trabajadores no vivían habitualmente en el lugar en que se ubicaba la fábrica, pero también vemos en alguna ordenanza cómo se manda explícitamente que se elija a trabajadores de la propia comarca. Una u otra decisión dependía del momento en que se encontrase el contencioso entre los privilegios de los monederos y los derechos de los ciudadanos de los concejos reclamados en cada reunión de Cortes, especialmente en el siglo XV.

No se conoce ningún contrato de acuñación en el ámbito de la corona de Castilla, pero, si extrapolamos lo conocido para otros territorios, podemos decir que en ellos se fijaba el peso y la ley de las monedas que se fabricarían, la cantidad y los plazos de entrega, así como los beneficios del monarca y de los arrendadores. Es cierto que todos estos datos, excepto el del beneficio del arrendador, figuran en las ordenanzas castellanas, pero eso no excluye, a mi juicio, la existencia, además, de contratos privados que no han llegado hasta nosotros.

El director técnico de la fábrica era el maestro de moneda. Ya hemos visto que inicialmente podía ser, además, el arrendador de la emisión. Pero en Castilla esta figura va perdiendo relieve con el tiempo, de manera que con la llegada del siglo XV aparece la figura del tesorero como responsable a la vez de la parte técnica y de la administrativa, quedando el puesto de maestro como un empleado más, encargado del manejo de la balanza, una de las varias operaciones que el maestro inicial dominaba y controlaba. Recordemos que, además de comprobar el peso exacto de cospeles y monedas en sus respectivas libranzas, realizaba la aleación de metales, y que esta, en principio, era una operación consistente en mezclar metales en sólido ${ }^{23}$, para lo que había que ser experto en pesarlos y analizar su composición, tarea esta última que pasaría a ser realizada por el ensayador. La fundición de los metales aleados también la podía realizar el maestro, pero también dio origen a un operario especializado, el fundidor, que no aparece demasiado en las ordenanzas medievales, ausencia que debemos interpretar como que era el maestro quien fundía o que la fundición se realizaba fuera del recinto de la casa e incluso fuera del ámbito de la ordenanza, que no se ocupa demasiado de esta operación. En otros países el director sigue denominándose maes-

el ámbito inglés, J. Craig, The Mint y N.J. Mayhew, From Regional, pp. 83-178. Sobre los Países Bajos, P. Spufford, Mint organisation, pp. 239-261.

${ }^{22}$ La mayor parte de los detalles concretos sobre el aspecto empresarial están tomados de la documentación estudiada por F. Dumas-Dubourg, Le monnayage y de P. Spufford, Mint organisation.

${ }_{23}$ J. Torres, Alear, aleación, pp. 129-150. 
tro de moneda incluso durante la Edad Moderna, aunque hay que suponer que sus funciones, y su extracción social, serían las mismas que las de nuestro tesorero. Estas diferencias en las denominaciones tienen que ver más con la historia de las lenguas que con la historia de las técnicas. Mientras que en otras lenguas vecinas el sentido de magister se especializó en la marca de jerarquía y mando, en castellano acompañó a los personajes que poseían unos conocimientos, y, al bajar estos en la jerarquía, bajó con ellos su denominación. Con el paso de los siglos le sucedería lo mismo al nombre tesorero, término bastante impropio, pues no lleva emparejada ninguna marca de jerarquía, y que pasaría a ser simplemente el encargado de la tesorería o caja.

La aparición de notables a cargo de oficios en las casas de moneda conlleva la llegada de otros personajes, llamados tenientes o lugartenientes del oficio que sea, que son quienes, en principio, ejercen realmente el oficio, aunque no debemos descartar que también los tenientes delegaran en otros subalternos que no aparecen documentados.

En la Corona de Aragón se conocen algunos reglamentos otorgados por el rey que regulaban el comportamiento de los empleados en el interior del establecimiento y el funcionamiento de su organización corporativa. A partir del siglo XIII se empiezan a conocer textos denominados privilegios de los monederos que contienen una serie de ventajas de todo tipo que el rey tiene que concederles, las más importantes eran la exención de determinados impuestos, lo que fue motivo de polémica constante en las Cortes, y un ámbito judicial propio que abarcaba todos los delitos excepto los muy graves, o lo que es lo mismo, que en teoría no podían ser perseguidos ni retenidos por la justicia ordinaria. La justicia privativa era impartida por los alcaldes específicos de la casa.

Durante el siglo XV, aunque no sabemos desde cuando, los empleados de la fábrica recibían, en el momento de ser admitidos en sus oficios, unos títulos personales que además eran anotados en libros de registro. Estos títulos los acreditaban como beneficiarios de los privilegios otorgados al colectivo al que pertenecían.

Los monederos europeos estaban organizados, desde muy antiguo, en corporaciones territoriales de ámbito muy amplio, llamadas en Francia serments. En la península ibérica debieron de existir este tipo de asociaciones territoriales, pero apenas hay algún indicio de que las de los reinos de León, Castilla, Navarra y Aragón se reunían periódicamente, a principios del siglo XIII, en el monasterio de San Claudio de León, en la Cofradía de los Monederos de los Cuatro Reinos. Sí tenemos menciones en las ordenanzas a los cabildos de obreros y monederos de cada fábrica particular, pero ninguna noticia de cómo se relacionaban entre ellos estos cabildos ${ }^{24}$.

\section{LA FABRICACIÓN}

La fabricación de la moneda por métodos manuales era un proceso múltiple, dividido en otra serie de procesos parciales pero la mayoría complejos, en el que podían llegar a intervenir muchas personas, todas ellas especializadas en la realización de un tipo de trabajo concreto. Todos los relatos actuales acerca del proceso de fabricación de la moneda en la Edad Media tratan de armonizar la información procedente de la documentación disponible, que no necesariamente forma conjuntos coherentes en el espacio y en el tiempo, uniendo así testimonios de escritos que quizá

${ }^{24}$ Sobre la reglamentación, privilegios y organización de los monederos: J. Torres, La fabricación, pp. 176-179; A. Estrada-Rius, El capítol; A. Estrada-Rius, Alcaldes; A. Estrada-Rius, Els col-legis; J.A. García Luján, Privilegios de los monederos; D. Peres, História dos moedeiros. 
no describan partes de un mismo un proceso, sino de procesos en los que podría haber ligeras variantes. Por ello, se aprecian algunas diferencias entre las propuestas de unos y otros estudiosos, aunque algunos, si no todos, destacan las variantes apreciadas en la documentación, que indican la existencia, en algunos casos, de diferentes formas de realizar una misma tarea. De ahí la importancia, con miras al rigor histórico, de proporcionar la procedencia y la fecha de la documentación utilizada.

Al conjunto de la fabricación de moneda se le suele denominar acuñación de moneda, pero la acuñación propiamente dicha no es sino el último, o el penúltimo, de los procesos parciales que la integran. Para realizarla se necesitan por un lado un objeto acuñable y por otro unos instrumentos para acuñarlo.

$\mathrm{Al}$ objeto que se acuña, que normalmente tendrá la forma de un disco de metal $^{25}$ de una composición y un peso dados, lo llamamos cospel, que es el nombre que recibe en la actualidad. En la Edad Media el cospel no disponía, en castellano, de un nombre propio, y era denominado dinero prieto, moneda o con el mismo nombre de la moneda que se va a acuñar (dinero, real, novén, etc.), siendo el contexto, y más concretamente su asociación con los obreros o con los monederos, lo que nos ayudará a discernir de qué cosa se está hablando ${ }^{26}$. Algo muy parecido sucede en catalán. Esto puede dar lugar a errores de interpretación de cierta importancia cuando, por no leer el contexto con suficiente amplitud, se puede creer que determinados procesos se realizan sobre la moneda, siendo en realidad el cospel el que los sufre. La elaboración de los cospeles era una tarea a su vez dividida en varias tareas sucesivas, y estaba a cargo de los obreros.

Los instrumentos de acuñar serán dos cuños o troqueles y un martillo. Los cuños se llamaban en castellano parejos. Estaban compuestos por un cuerpo de hierro forjado, realizado por un herrero, en uno de cuyos extremos se soldaba la pieza de acero o hierro acerado en que el grabador, conocido como tallador o entallador, había grabado los motivos pertinentes. Los pares de cuños no eran iguales entre sí, pues mientras el superior bastaba con que tuviera una forma cilíndrica, el inferior debía estar provisto en su parte inferior de una pieza en forma de clavo que se hincaba en un cepo de madera para mantenerlo fijado; gracias a su forma troncopiramidal o troncocónica, la base del cuño propiamente dicho actuaba además como cabeza del clavo, impidiendo la penetración en la madera más allá de lo conveniente. Además, como nota curiosa, apuntaremos que, desde el punto de vista de su fabricación, un par de cuños no estaba compuesto por dos piezas, sino por un cuño inferior y varios cuños superiores, puesto que estos se desgastaban y estropeaban más rápidamente a causa de su movilidad y de ser los que recibían el golpe de martillo, lo que iba deformándolos paulatinamente en el extremo golpeado ${ }^{27}$.

Los cuños y los cospeles eran entregados a los monederos para que acuñaran las monedas. El cospel se colocaba sobre el cuño inferior, lo más centrado posible, el cuño superior sobre el cospel y, con una maza, se golpeaba sobre el cuño superior. En el momento de la acuñación, parte de la masa metálica del cospel se desplaza hacia el interior de las cavidades del troquel, ocupándolas y dando lugar al relieve de la moneda, otra parte del metal tiende a expandirse hacia el exterior, con lo que la moneda se hacía levemente más amplia que el cospel.

\footnotetext{
${ }^{25}$ La única excepción, durante el periodo medieval, a la norma de la moneda circular, son los dirhams cuadrados (moneda de plata) de época almohade y sus imitaciones.

${ }^{26}$ J. Torres, Ordenanzas medievales, pp. 410, 472 y 709.

${ }^{27}$ Sobre el grabado de los cuños con una perspectiva histórica, véase B. Bouyon, Études de gravure, pp. 31-39; Outillages monétaires de Charles VIII, publicado anteriormente como anexo de la obra de J. Belaubre, Monnaies médievales, 1988, pp. 363-373, y en B. Bouyon, Ainsi frappait-on, pp. 22-26.
} 
El horario de la fábrica estaba marcado por las horas de sol, quedando prohibido trabajar una vez hecha la oscuridad.

Además de los obreros, los monederos y los grabadores y herreros, había en las casas de moneda un maestro de moneda o tesorero, un ensayador, dos guardas, un fundidor, un escribano y dos alcaldes ${ }^{28}$.

Como todos los medievalistas deben saber, el escribano no era un simple escribiente, sino algo más parecido a lo que luego ha sido el notario. Aunque probablemente escribiera él mismo algunos documentos, no hay que descartar que tuviera uno o varios escribientes a su cargo. Tenía que dar fe por escrito de prácticamente todas las operaciones relacionadas con la fabricación, y poseía una de las tres llaves de varias de las arcas en que se guardaban caudales y documentos. En las ordenanzas castellanas no se menciona nunca la figura de un contador, por lo que probablemente el escribano también redactase las cuentas de acuerdo con la documentación suelta proporcionada por el maestro o tesorero. La secuencia de fabricación y las compras de materiales, se pueden seguir casi con lupa en aquellas fábricas que han logrado conservar a lo largo del tiempo los ocho libros preceptivos correspondientes a una época determinada: libro de entrada de metales, de aleaciones, de fundiciones, de obreros, de blanquición, de monederos, de libranzas y de compras o gastos generales ${ }^{29}$.

\subsection{Antes de los obreros}

La primera tarea que tenía que emprender el arrendador de una emisión de moneda era conseguir los metales necesarios para llevarla a cabo. La redacción de las ordenanzas castellanas da a veces la sensación de que los metales eran aportados por el rey, pero, leyendo con detenimiento, podemos ver que se dan órdenes estrictas para que se den facilidades a los arrendadores para conseguir y mover los metales a través del territorio.

Una vez aprovisionado el taller de la materia prima y de otros elementos y útiles necesarios, había que proceder a la labor más compleja de todas las que intervenían en la fabricación, que consistía en poner los metales a la ley ${ }^{30}$. La ley es la expresión en términos relativos de la pureza de un metal. En la actualidad se expresa en tanto por mil, pero en la Edad Media, y en general hasta el sistema métrico decimal, se expresaba en unas unidades específicas que variaban para el oro y la plata. La ley del oro se expresaba en tanto por 24, denominándose quilate a cada una de las 24 unidades; cada quilate se subdividía a su vez en cuatro granos, teniendo por tanto, el oro puro 96 granos de ley. La ley de la plata se expresaba en tanto por 12, cada una de las 12 unidades se llamaba dinero y se subdividía en 24 granos, teniendo la plata pura 288 granos de ley.

Durante la Edad Media en Europa la moneda tenía como base la plata. En tiempos de Carlomagno se inició la acuñación de una pequeña moneda de plata de

\footnotetext{
28 Sobre el personal de las casas medievales, J. Torres, Ordenanzas medievales, pp. 418-484; J. Torres, La fabricación, pp. 176 y ss.; R. Córdoba, Ciencia y técnica, pp. 90-123.

${ }^{29}$ Sobre los libros, cuyos mejores ejemplos se encuentran en el Archivo de la Corona de Aragón, R. Córdoba, Ciencia y técnica, pp. 29-36 y algunos de los documentos transcritos en su Apéndice.

${ }^{30}$ Las operaciones más relacionadas con las técnicas metalúrgicas y con las operaciones matemáticas implicadas en ellas han sido magistralmente tratadas y estudiadas en G. Céspedes, Las cecas indianas, pp. 101-146; R. Córdoba, Cálculo, técnica, pp. 83-128; y R. Córdoba, Ciencia y técnica, pp. 151-207 y 238-299. Un resumen del proceso de aleación en J. Torres, La fabricación, pp. 185186. Para familiarizarse con los sistemas de medida de peso y ley, véase pp. 170-173 de este último trabajo.
} 
buena calidad, llamada dinero, que fue poco a poco envileciéndose con adición de cobre hasta convertirse en el dinero de vellón de la Plena y Baja Edad Media. La adición de cobre no respondía tanto a un ánimo de engaño o de obtención de mayores beneficios, cuanto a la producción de una moneda de menor valor que pudiese ser usada para la mayor parte de las necesidades de la economía, desde pagos relativamente altos hasta los cotidianos, incluyendo salarios y pagos de impuestos. Como por el momento era impensable una moneda sin contenido de metal precioso, había que mezclar la plata con cobre para que la moneda tuviera un tamaño suficiente. La moneda de plata fina vuelve a aparecer a lo largo del siglo XIII. Se trata de piezas de mayor diámetro, de casi 12 dineros de ley y con un valor en el momento de su creación de doce de las piezas de pequeño tamaño, por lo que recibieron el nombre de sueldos, ya que el sueldo era un conjunto de 12 dineros en el sistema monetario de Carlomagno. En Castilla, este tipo de moneda se denominó real, y no está claro que en algún momento equivaliera a doce piezas de moneda menuda, dado que su introducción coincide con un cambio metrológico en la moneda de vellón. La moneda de oro, casi siempre de alta calidad, se acuña muy esporádicamente durante la Edad Media, pues el oro no era un metal abundante en Europa y, cuando lo había, se admitía sin ningún problema en bruto, al peso, como medio de pago para grandes transacciones.

Para obtener la plata y el oro finos había primero que afinarlos y luego mezclarlos con una pequeña proporción de liga para mejorar su dureza y resistencia al desgaste. La obtención del vellón o plata baja de diferentes leyes exigía la elaboración de aleaciones, calculadas primero sobre el papel y realizadas luego en el taller. Existían también tablas de aleaciones para evitar tener que hacer las operaciones, al menos en los casos más normales. Siempre que fuera posible evitarla mediante mezclas, se evitaría la afinación, que era una técnica compleja y encarecía notablemente la fabricación.

En la operación de puesta a la ley de los metales, que se realizaba en la fundición, intervenían, desde el punto de vista técnico, el maestro de moneda, el fundidor o el afinador y el ensayador. Los tres primeros, dependiendo de la época y del tipo de taller pueden aparecer o no, es decir, que cada uno de ellos por separado estaba capacitado para realizarla y normalmente no coexistían los tres oficios en una misma casa. Las ordenanzas castellanas apenas nombran la operación de fundir metales, siendo necesario recurrir a la documentación de la Corona de Aragón y otros territorios para tener una mínima idea de cómo se realizaba. El ensayador, también estaba técnicamente capacitado para dirigir una fundición y afinación de metales, pero su función específica era el control de la ley de los metales en diversos momentos de la fabricación. Era, por así decirlo, uno de los varios agentes que el rey introducía en el proceso para que velaran por sus intereses o por el interés común.

Las ordenanzas medievales castellanas solo mencionan una vez los hornos de ensaye (Madrid 1462, 35) y una vez los de fundición y afinación (Segovia 1471, 7), y nunca los de recocido. También una vez (Medina 1497, 55) se menciona el uso de crisoles. Nunca se especifica de qué tipo han de ser ni los hornos ni los crisoles. El libro del Alguarismo (p. 220 y ss., ff. 126v y ss.) describe el horno de ensayes, asî como las copelas y el modo de fabricarlas. En la documentación catalana hay indicios del uso de dos tipos de crisoles, probablemente de metal y de material refractario: caça y cresol $^{31}$.

Una vez puestos los metales a la ley mediante la mezcla de metales y su fundición o afinación, el metal fundido se vertía en rieleras de un formato adecuado a los requerimientos de la fabricación de los cospeles, y los rieles resultantes eran

\footnotetext{
${ }^{31}$ J. Torres, La fabricación, p. 185.
} 
entregados a los obreros de las hornazas. No voy a insistir en que, cada vez que se manipulaba la composición del metal o las piezas llegaban al final de un proceso durante el cual podría darse una sustitución fraudulenta, el ensayador intervenía sobre una muestra para comprobar que se seguían cumpliendo las especificaciones técnicas requeridas.

\subsection{Los obreros}

De modo genérico, el trabajo realizado en las hornazas consistía en convertir los rieles recibidos en cospeles o discos de metal. Este trabajo estaba encomendado a operarios denominados genéricamente obreros que trabajaban en pequeños grupos encabezados por un capataz que era a la vez el jefe y el representante de todo el equipo en las asambleas. Pero ¿cómo se realizaba esto?

A juzgar por las representaciones iconográficas que han llegado hasta no$\operatorname{sotros}^{32}$, parece que lo más habitual en nuestro ámbito tecnológico era la obtención de unos rieles alargados, estrechos y finos que primero se aplanaban hasta un espesor semejante al de la pieza final y luego se recortaban en cuadrados ${ }^{33}$. Estos cuadrados se aplanaban uno por uno en una especie de acuñado en plano sobre un yunque y luego se les recortaban las esquinas. Entonces eran pesados de uno en uno y ajustados a peso de acuerdo con los patrones de peso llamados dinerales ${ }^{34}$; podría haber dinerales con el peso máximo y con el peso mínimo admitidos para la emisión, pero es probable que se tendiese a ajustar las piezas cerca del peso máximo, puesto que todavía podían menguar de peso pero no aumentar; lo cierto es que el método de ajuste no está descrito con minuciosidad en la documentación conocida. Después de ajustadas, las piezas eran sometidas a una operación de redondeo e igualado golpeando los bordes de un conjunto de ellas sujetas con unas tenazas específicas para tal fin. Antes de dar los cospeles por terminados, podía ser necesario aplanarlos de nuevo uno por uno para eliminar las rebabas e irregularidades que quedasen y darles la forma definitiva.

${ }^{32}$ Las imágenes que presento en este trabajo, pertenecientes a la portada de la iglesia de Santiago, en Carrión de los Condes, han sido reproducidas ya, junto con las de la portada de Arenillas de San Pelayo, en varios de mis trabajos; quizá las mejores reproducciones, aunque algo pequeñas, son las de J. Torres, Monederos de piedra, donde además se explica cada una de las imágenes. Como casi todo, se pueden encontrar en internet, en concreto las de Carrión se pueden ver, aunque no individualmente, en http://www.flickr.com/photos/rabiespierre/2314053737 y siguientes (diciembre 2011) y las de Arenillas en http://www.flickr.com/photos/rabiespierre/2981850756 y siguientes (diciembre 2011). En las páginas de R. Córdoba, Ciencia y técnica, se puede encontrar un buen repertorio de las ilustraciones conocidas, casi todas de época moderna.

${ }^{33}$ La secuencia de la fabricación de cospeles en J. Torres, La fabricación, p. 186-192; R. Córdoba, Ciencia y técnica, pp. 208-224. También en la descripción que, según documentos de los siglos XVI y XVII, en M. Bompaire, F. Dumas, Numismatique médiévale, p. 488. A. Arles, Entre monnayage, pp. 66-113, partiendo de textos, restos arqueológicos y experimentos, ha establecido una secuencia de operaciones compuesta en total por 26 manipulaciones sucesivas, entre martilleos y recocidos, más compleja que la descrita aquí, pero que debemos tomar en adelante como punto de referencia, siempre teniendo en cuenta la posible diversidad de metodologías entre unos talleres y otros. Hay que señalar que los documentos franceses son bastante más ricos en vocabulario que los ibéricos, con lo que ello implica de clarificación, por un lado, y por otro, a veces, también de confusión, pero no es este el lugar apropiado para ocuparse de la parte lingüística de este tipo de investigaciones.

34 También se llamaban dinerales las pesas ligerísimas y de precisión absoluta utilizadas en los ensayes. Su fabricación viene explicada en J. de Arfe y Villafañe, Quilatador, 1572, ff. 5v-7r y 23r23v. El libro del Alguarismo (ff. 134r-134v) explica cómo calcular el peso de los dinerales de ajuste, pero no cómo fabricarlos. 
Los restos inservibles procedentes de los recortes se denominaban cizalla. Los párrafos que le dedican las ordenanzas castellanas son difíciles de interpretar. Lo único que se desprende de su lectura es que podían producir cizalla tanto los obreros como los monederos (aunque estos no cortaban nada), y es de la de estos últimos de la que más se ocupan. Aunque no se explica, tenemos que suponer que la cizalla producida por los monederos se refiere a las monedas mal acuñadas o rotas, es decir, las que no cumplen las especificaciones de aspecto que veremos más adelante ${ }^{35}$. Céspedes, partiendo de documentación peruana de Edad Moderna ${ }^{36}$, afirma que en cierto momento los restos de corte se entregaban junto con la moneda acuñada a los dueños del metal ingresado (está hablando, evidentemente de plata fina), aunque más adelante comenta que "más tarde" la cizalla se enviaba a fundir ${ }^{37}$. En su tesis, A. Arles ${ }^{38}$ estudia y calcula la verosimilitud de las cifras proporcionadas por la documentación que maneja, que le parecen muy bajas. Como Arles no parece distinguir la cizalla de los obreros de la de los monederos, e incluso parece que a veces no aprecia la distinción terminológica entre obreros y monederos, puede que las cifras bajas correspondan a la cizalla de los monederos, que son las que se encuentran en la reglamentación castellana y que eran mucho menores que las relativas a la cizalla de los obreros. Por otra parte, no parece necesario limitar la cantidad de cizalla producida por los obreros, es decir, en las operaciones de corte, puesto que, si el tamaño de los rieles era homogéneo, se trataría siempre de cantidades muy semejantes, y sí la producida por los monederos, que dependía de su torpeza o falta de atención.

Tanto los aparatos para laminar metales por medio de rodillos como los utensilios para recortar piezas circulares de las láminas de metal, parecidos a los sacabocados, existían al menos a finales de la Edad Media. Leonardo da Vinci proponía en uno de sus manuscritos esta técnica para la ceca de Roma, dibujando incluso el sacabocados junto a otros artefactos para acuñar a martillo ${ }^{39}$, pero no hay constancia de que nunca se utilizasen sacabocados manuales en la fabricación de moneda legal. Las ordenanzas no mencionan laminadores, ni siquiera para prohibirlos. En cuanto al sacabocados, podría permanecer oculto tras alguno de los términos de difícil interpretación, aunque no parece probable. El motivo para que no se utilizase este tipo de técnicas es que, por muy rudimentaria que pueda parecer la laminación a martillo, combinada con el ajuste fino de las piezas mediante recortes, aportaba gran precisión a la fabricación de cospeles de un peso determinado, y sobre todo, minimizaba el peso total de los recortes inservibles, que había que volver a procesar. Hay que pensar que la tecnología de laminación a rodillo no permitía alcanzar los finos espesores requeridos por las monedas medievales o incluso una uniformidad de la lámina; finalmente, el uso del sacabocados era inútil, si seguía siendo necesario recortarlos a tijera para ajustarlos al peso.

Las láminas metálicas, y luego los cospeles tenían que ser, además, sometidos a la operación de recocido, al menos cada vez que eran aplanados y, desde luego, antes de ser acuñados. El recocido consiste en un calentamiento moderado del metal

35 J. Torres, Ordenanzas medievales, pp. 635-640.

${ }^{36}$ G. Céspedes, Las cecas indianas, pp. 149-151. Su fuente es C. Lazo García, J. Torres Bohl, L. Arana Bustamante, La hornaza, 1991.

${ }^{37}$ G. Céspedes, Las cecas indianas, p. 163.

38 A. Arles, Entre monnayage, 2009, pp. 413 y ss.

39 Se puede ver el folio 43 del manuscrito $\mathrm{G}$ del Institut de France en la página web del Museo Galileo de Florencia: http://brunelleschi.imss.fi.it/genscheda.asp?appl=LIR\&Xsl=paginamanoscritto $\&$ chiave $=101678$ [consulta: diciembre 2011]. 
que podía hacerse en el suelo de la hornaza entre brasas de carbón ${ }^{40}$, para intentar evitar su oxidación. Con el recocido, el metal recuperaba la estructura cristalina interna inicial que permitía su forja.

Antes de blanquear los cospeles, se realizaba su libranza, operación que consistía en la comprobación de que su peso estaba acorde con lo estipulado en las ordenanzas. Se comprobaba también que el peso de los cospeles más el de la cizalla producida por cada obrero era igual al peso que se le había entregado en rieles ${ }^{41}$.

El blanqueado era una limpieza química, mediante el baño en una solución ácida a base de sal común y tartrato de potasio, conocido como tártaro o rasuras en castellano y en valenciano como ros de bota. El método está bastante bien descrito en un documento de la casa de moneda de Valencia (Valencia 1417) ${ }^{42}$. En el caso de las aleaciones de plata baja, los cospeles salían del baño con un aspecto plateado efímero, pues producía un enriquecimiento superficial, eliminando suciedad física y los óxidos. Hasta ahora se pensaba que el blanqueado eliminaba también parte del cobre contenido en esa primera capa, pero los experimentos de Adrien Arles le hacen proponer que esta corrosión y eliminación de cobre se ha realizado ya en los recocidos y martilleos previos, y que el ácido solo se lleva el óxido de cobre; además, no se produce ningún enriquecimiento superficial en aleaciones con menos del $8 \%$ de plata, lo que, traducido a la lengua técnica medieval, equivale a menos de un dinero de plata (23 granos $)^{43}$. Fuera como fuera, aunque en cantidades mínimas, las piezas salían del blanqueo con menor peso y mejor ley. Por ello, la comprobación de la ley de los cospeles que se habían pesado cuando aún estaban negros, se realizaba después del blanqueo que se constituía en una especie de tierra de nadie entre el trabajo de los obreros y el de los monederos.

\subsection{Los monederos}

Los cospeles eran entregados a los monederos en lotes, de acuerdo con su capacidad de trabajo durante un periodo de tiempo. Las ordenanzas suelen hablar de un día, pero es de imaginar que durante una jornada recibirían varios recipientes de cospeles, y que, además, efectuarían paradas para descansar, durante las cuales no podrían quedar abandonados ni los cospeles ni las monedas acuñadas ni los propios cuños.

Los monederos recibían los troqueles de manos de los guardas cada mañana y se los volvían a entregar al finalizar la jornada. Los cuños eran guardados hasta la jornada siguiente en arcas específicas para ese menester.

Las monedas acuñadas eran pasadas por un control de calidad en lo referente a su aspecto físico, que era realizado por los guardas o, en algunos casos, por un operario especializado llamado triador. Las monedas mal acuñadas eran consideradas como cizalla.

\footnotetext{
${ }^{40}$ Este sistema de recocido lo describe G. Céspedes, Las cecas indianas, p. 148. Los diversos recocidos o recochos, denominados hornillas se ordenaban y numeraban: primera hornilla, segunda hornilla, etc. Si se quiere profundizar en los efectos del recocido, véase A. Arles, Entre monnayage, pp. 85 y ss.

${ }^{41}$ Sobre la libranza de los cospeles véase J. Torres, La fabricación, pp. 189-191.

42 J. Torres, La fabricación, pp. 191-192.

${ }^{43}$ A. Arles, Entre monnayage, pp. 459-503. Dada la fácil accesibilidad de este texto en internet, no parece necesario resumir sus novedosas aportaciones. En la documentación peninsular no he encontrado ninguna mención al blanqueado con aguafuerte que, según Arles, se utilizaba con anterioridad a la utilización del tartrato de potasio.
} 
Luego se efectuaba el control de peso de las monedas, comprobándose que las piezas admitidas más las no admitidas y los posibles fragmentos producidos coincidieran en peso con lo entregado para monedear.

La libranza de la moneda consistía en comprobar el peso de determinadas cantidades de piezas válidas tomadas al azar. Finalmente se comprobaba también la ley del producto acabado ${ }^{44}$.

\section{SiSTEMAS DE CONTROL}

Al tratarse de una fabricación de alta importancia económica que, por lo general, reportaba unos beneficios al rey, pero que también podía ocasionar daños tanto a la hacienda real como a la economía general del reino si se realizaba fraudulentamente, la fabricación de la moneda estaba sometida a una serie de controles de calidad que podemos resumir en tres categorías: el control de ley o composición, el control de peso y el control de aspecto. Las ceremonias en que se solemnizaban estos actos de control se celebraban con la asistencia de varios de los oficiales mayores, incluido el escribano que daba fe. Desde el punto de vista técnico, el control de ley era responsabilidad del ensayador, el control de peso del maestro o tesorero y el control de aspecto del triador. Desde el punto de vista administrativo, el rey controlaba en última instancia estos tres tipos de operaciones a través de sus representantes en la fábrica, los guardas, que en alguna ocasión eran también responsables del control de aspecto por no haber triador. El hecho de que los guardas fueran dos tendía a dificultar su propia conducta irregular mediante la vigilancia mutua. En documentos franceses y flamencos se constata la presencia de contraguardas que, según Spufford, garantizaban los intereses de los mercaderes que llevaban sus metales a acuñar ${ }^{45}$. En el privilegio de Lorca (Lorca 1297) se mencionan unos sobreguardas que no vuelven a aparecer en el resto de ordenanzas.

El propio producto, la moneda, llevaba además impresos algunos símbolos que permitían su control a posteriori, una vez puesta en el mercado. Se trata de las marcas de taller en todas las emisiones y de las marcas de ensayador o responsable de la ley en las de plata y oro. Si se descubría una pieza en circulación falta de ley siempre era posible exigir responsabilidades tanto al taller que la emitió como al técnico que aprobó su composición. En Castilla no se ordenó la inclusión de la marca de ensayador hasta la ordenanza de 1497, por lo que hay que suponer que durante la Edad Media había sido suficiente la inclusión de la marca de ceca para identificar al responsable de la calidad metálica de la moneda. Cada taller debía guardar muestras del ensaye y peso de cada libranza de moneda acuñada en el arca llamada de encerramientos para su posterior comprobación en caso necesario.

\subsection{Ensaye}

Dentro de la fabricación de la moneda, se denominaba ensaye a la operación mediante la cual se comprobaba que la composición metálica de una aleación era la indicada en las ordenanzas o leyes. El término se ha convertido con el tiempo en el más moderno ensayo, aunque ambos aparecen en el Diccionario de la RAE.

\footnotetext{
44 El trabajo de los monederos en J. Torres, La fabricación, pp. 192-194, la libranza de moneda en pp. 194-196.

${ }_{45}$ P. Spufford, Mint organisation, pp. 246 y 248. Según Spufford o la documentación que maneja (p. 246) los guardas eran la máxima autoridad de la ceca, por encima incluso de los maestros.
} 
La composición metálica se medía mediante la ley, cuyas unidades ya he explicado más arriba. Era responsabilidad del maestro hacer que los metales que recibía, que podían ser de diferentes leyes, fueran aleados de acuerdo con lo prescrito, pero, una vez realizada la aleación, era el ensayador quien tenía que comprobar la exactitud de la ley en varios momentos de la fabricación (de los rieles, de los cospeles y, a veces, de las monedas), e incluso estaba autorizado para realizar análisis por sorpresa, tanto en las hornazas de los obreros como en los talleres de acuñación.

El método de ensaye más antiguo y más común, aunque por su relativa sencillez quizá no deba considerarse ensaye, es el de la piedra de toque. Consistía en comparar el color dejado por la muestra al frotarla sobre la piedra de toque con el color dejado por unos patrones de ley conocida. El método requería buen ojo, pero el de un experto obtenía excelentes resultados. La sencillez operativa del método no implica un retraso tecnológico, pues los patrones debían ser fabricados con una precisión nada sencilla de conseguir, a causa de las pequeñas dimensiones de las piezas utilizadas como patrón y de las leves diferencias de contenido entre patrones contiguos.

Pero el método oficial en la Edad Media y hasta casi la Edad Contemporánea era el que hoy conocemos como copelación, entonces llamado ensaye por fuego. Sin embargo, hay que destacar que la legislación solo empieza a especificar que el ensaye sea por fuego a mediados del siglo XV. Y ya sabemos que, a veces, la insistencia de la legislación en una norma suele significar que no se cumple como debería.

El ensaye por fuego ${ }^{46}$ no era otra cosa que una afinación de precisión dado que las cantidades de metal utilizadas en la operación eran las más pequeñas posibles, aunque también se tenía en cuenta que su peso fuera proporcional o parangonable a las cantidades utilizadas en la fabricación para facilitar la extrapolación de los cálculos.

El ensaye de la plata consistía en fundir la cantidad elegida junto con otra cantidad determinada de plomo en unos pequeños crisoles especiales llamados copelas, en hornos específicos e introduciendo la copela en una mufla que concentraba el calor e impedía la caída de impurezas en el interior de la copela. El plomo desaparecía durante el proceso llevándose con él otras posibles impurezas, dejando en la cavidad de la copela una bola de plata pura, cuyo peso se comparaba con el de la muestra inicial para calcular la cantidad de liga y, por tanto, la ley. Como el plomo siempre se presenta con una cierta cantidad de plata, había que ensayar también el plomo utilizado, en cantidad igual a la empleada en el ensaye, y descontar la cantidad de plata aportada por él al experimento, lo que se hacía colocando en el plato de las pesas de la balanza el peso equivalente a la plata extraída del plomo o la propia muestra de plata procedente del ensaye del plomo. De esta forma, el resto de las pesas indicaban el peso exacto de la plata contenida en la muestra.

Si el ensaye era de un trozo de oro, una vez eliminado el cobre por copelación, era necesario separar la plata mezclada con el oro mediante el recurso a baños de aguafuerte.

Las cantidades que se ensayaban eran muy pequeñas, por lo que tanto los pesos (balanzas) utilizados como las pesas tenían que ser de una precisión extrema. Las pesas dinerales utilizadas en el ensaye eran fabricadas por los propios ensayadores por un método que explica Juan de Arfe en su tratado.

\footnotetext{
${ }^{46} \mathrm{El}$ único texto medieval en castellano sobre el ensaye de metales y todo lo relacionado con él es el editado en B. Caunedo, R. Córdoba, El arte del alguarismo, pero por su cercanía cronológica se puede ver también J. de Arfe, Quilatador, 1572. El primero es quizá más confuso, dado que el manuscrito conservado fue copiado con algo de descuido, pero se compensa con una mayor minuciosidad, dado que su público eran otros ensayadores o aprendices de ello. Las dificultades de lectura se pueden salvar recurriendo a la introducción realizada por R. Córdoba a ese texto y en los lugares ya citados al hablar de la metalurgia de su Ciencia y técnica. Un resumen más breve en J. Torres, La fabricación, pp. 180-185.
} 


\subsection{Levadas}

Desde principios del siglo XV se llama levada a la elección al azar de una pieza o conjunto de ellas para comprobar su peso o su ley, y más concretamente a una operación que se realizaba sobre un conjunto representativo de cospeles sin blanquear para comprobar que cumplían con la talla ordenada, y, más tarde, sobre un conjunto de cospeles blanqueados o de monedas acuñadas, para comprobar que se ajustaban a la ley. Anteriormente se aludía a esta operación como libranza o delibranza, lo que ocasiona una cierta confusión terminológica, ya que esta última la asociamos a la entrega de material, que es el sentido que parece tener cuando convive con levada, aunque también puede haber una cierta imprecisión en el uso.

La talla, expresada en piezas por marco (la unidad de peso para metales), indicaba de un modo indirecto el peso de cada una de las piezas, pero al estar referido a un conjunto mínimo de ellas convertía el peso unitario en una magnitud que podía variar, siendo compensado el peso inferior de unas piezas por el peso superior de otras. Sin embargo, como no era admisible una variedad de pesos completamente arbitraria, se ponían también unos límites dentro de los cuales podía oscilar el peso de cada una de las piezas. Las piezas por encima de la tolerancia se denominaban fuertes, y las que no alcanzaban el límite inferior se llamaban febles. Estas normas eran válidas sobre todo para las piezas pequeñas de vellón, que tenían poco valor, pues las monedas de plata fina y, sobre todo, las de oro, no solo tenían que cumplir con el peso de un modo más rígido, sino que luego, al salir al mercado, eran comprobadas minuciosamente por quienes las recibían, a pesar de que, a veces, las leyes prohibían pesarlas, dado que el hecho de estar acuñadas por un poder efectivo obligaba a quienes las recibieran a reconocer el valor que dicho poder les hubiera otorgado. Sin embargo, la moneda de oro siempre se pesaba, puesto que tarde o temprano su destino era un territorio ajeno al del poder que la acuñó, y en ese intercambio solo se le reconocería su equivalencia internacional si su peso era correcto.

Para proceder a una levada de peso se escogía un peso determinado de piezas y se comprobaba que la cantidad de estas cumplía o bien con la talla exacta o bien con los límites impuestos. Las ordenanzas medievales solían mandar que se compensasen las libranzas febles con otras fuertes, pero hay indicios de que esto no se cumplía, sino que, por el contrario, se intentaba jugar con la permisividad en el peso en aras de obtener el mayor número posible de piezas ${ }^{47}$.

\subsection{Control de aspecto}

Denomino control de aspecto a lo que sería un control de calidad propiamente dicho, es decir, de las características externas de las piezas fabricadas. Este tipo de control se especifica en todas las ordenanzas medievales, incluyendo la de 1497, bajo cuya vigencia se estuvieron fabricando monedas con forma irregular en los siglos XVI y XVII.

Este tipo de especificaciones se determinan de manera vaga respecto a sus características positivas, como que estén bien hechas, bien redondas, limpias y bien acuñadas, siendo más precisa la parte negativa, es decir, cuando se enumeran los defectos que no deben tener las piezas: mal hechas, laídas, cortas, quebradas o quebrantadas, bezudas, remolidas o remoladas, pieza menos, trassalidas, mal engranadas. A pesar de su supuesta precisión, estos términos nos dejan hoy en día bastante perplejos, pues se trata también de adjetivos vagos o incluso desconocidos o copiados servilmente de otras lenguas.

${ }^{47}$ La levada de peso de los cospeles se describe en J. Torres, La fabricación, pp. 189-191; R. Córdoba, Ciencia y técnica, pp. 132-136. 


\subsection{Libranza de la moneda}

Con los controles de calidad terminaba la fabricación de la moneda propiamente dicha. Una lectura literal de las ordenanzas (la más explícita al respecto es $\mathrm{Ma}$ drid 1462) indicaría que, una vez procesados los metales ingresados por particulares, les eran entregados en forma de monedas, con la detracción de las cantidades estipuladas en concepto de gastos de acuñación (braceaje) y derechos de señoreaje, que eran las cantidades que se abonaban al titular del derecho de acuñar, el rey, quien, a veces, renunciaba a cobrarlos, se supone que como incentivo en tiempos de escasez de metales acuñables.

En el caso de los metales preciosos, es probable que, efectivamente, el propietario de una remesa de metal recibiera las monedas elaboradas con el metal que aportó, pero en la moneda de vellón la entrega sería el resultado de toda una serie de cuentas y equivalencias. El hecho de que se establezca que el orden de salida debe ser el mismo que el de entrada parece implicar que el material recibido no se correspondía necesariamente con el entregado.

$$
* * *
$$

La moneda medieval no era, como hoy, un producto sin apenas valor al que se concede uno simbólico y representativo, sino que, al estar realizada en metales nobles, tenía un valor intrínseco, y por ello su fabricación estaba doblemente sometida a controles de seguridad. En ocasiones se permitía a los particulares llevar sus metales a las fábricas de moneda para que se los transformaran en moneda corriente.

La fabricación de moneda era una actividad común a toda la Europa medieval y se realizaba de una manera semejante, aunque con ligeras variantes en algunos procesos, en los distintos lugares. El trabajo estaba perfectamente regulado, planificado y dividido en actividades realizadas cada una de ellas por operarios especializados.

A lo largo del periodo, los lugares en que se fabricaba la moneda pasaron de ser pequeños talleres, a menudo ambulantes, a fábricas estables que empleaban a varios cientos de trabajadores, aunque de modo intermitente, salvo en las cecas de las ciudades más ricas.

\section{ILUSTRACIONES}

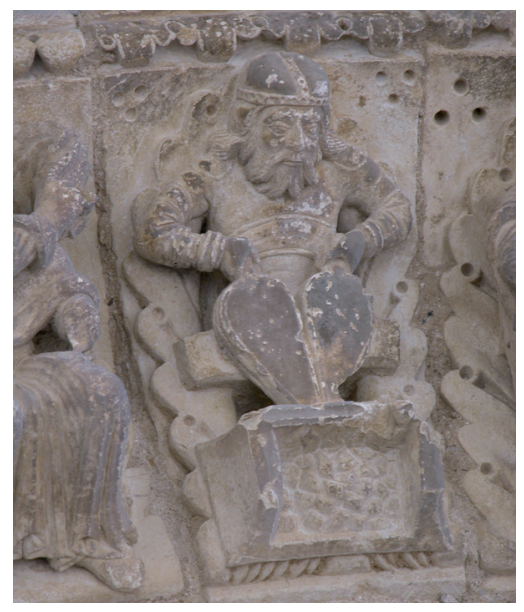

Fig. 1. Operario accionando los fuelles de un horno. Iglesia de Santiago (Carrión de los Condes). 


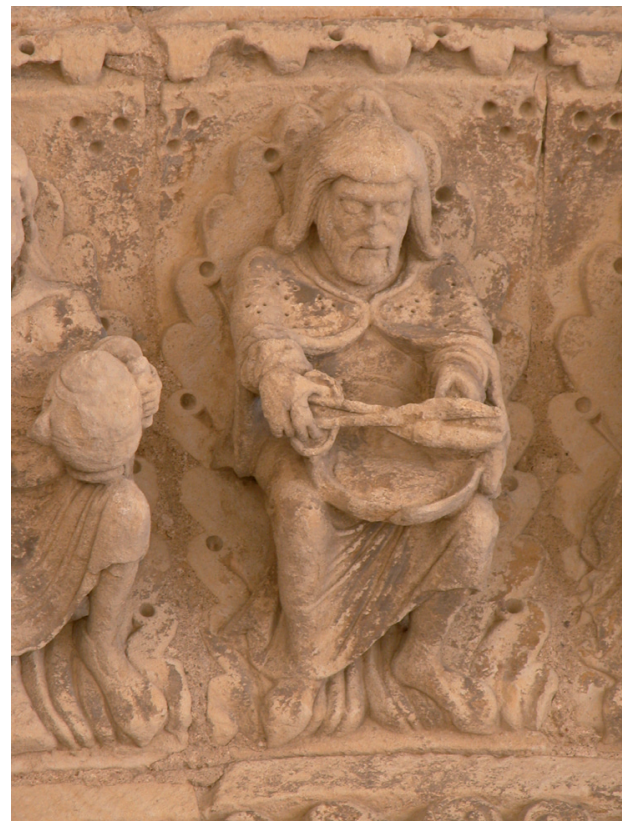

Fig. 2. Obrero recortando cospeles. Iglesia de Santiago (Carrión de los Condes).

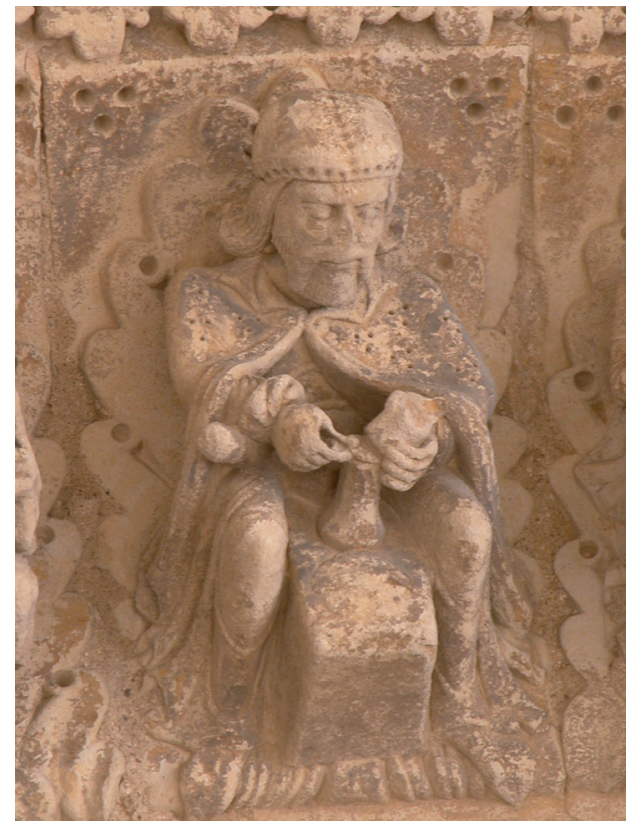

Fig. 3. Monedero colocando un cospel sobre el cuño inferior. Iglesia de Santiago (Carrión de los Condes). 


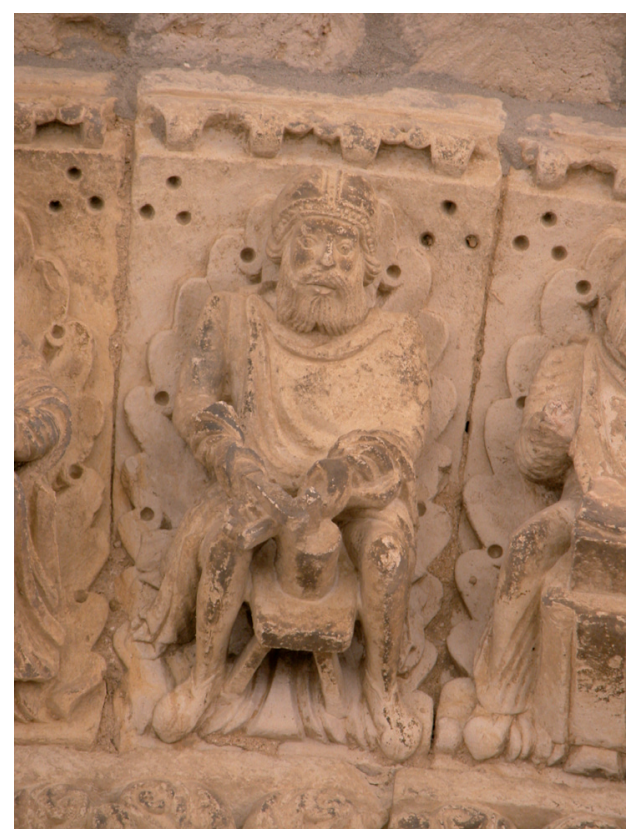

Fig. 4. Herrero fabricando un cuño. Iglesia de Santiago (Carrión de los Condes).

\section{APÉNDICES}

\subsection{Relación cronológica de las principales ordenanzas monetarias} medievales castellanas que se ocupan a fondo de la fabricación de la moneda

Lorca 1297: Ordenamiento de Fernando IV para acuñar moneda en Lorca, Archivo Municipal de Lorca, pergaminos de Fernando IV, núm. 17. Ediciones: Rafael Espín Rael, Privilegio para labrar moneda en Lorca, dado en Toro, por el rey Fernando IV, en 24 de octubre de la era de 1335, Lorca, 1936; Juan Torres Fontes, Repartimiento de Lorca, Murcia, 1977, doc. XXV, pp. 95 ss. y Juan Torres Fontes, Documentos de Fernando IV, Colección de documentos para la Historia del Reino de Murcia V, Murcia, 1980, doc. XXII, p. 26 ss.

Murcia 1334: Archivo Municipal de Murcia, Cartulario 1352-82 eras, ff 112-113. Editado en Juan Torres Fontes, La ceca murciana en el reinado de Alfonso XI, en Mélanges offerts à Jean Gautier Dalché, pp. 295-313, Niza, 1983.

Sevilla 1369: Archivo Municipal de Murcia, Cart. Real 1405-18 eras, ff. 16r-17r. Editado en Lope Pascual Martínez, Documentos de Enrique II, Colección de documentos para la Historia del Reino de Murcia VIII, Murcia, doc. V, pp. 7-10.

Cuenca 1400: Archivo General de Simancas, Diversos de Castilla 4, 57. Editado parcialmente en Juan Bautista Barthe, Colección de documentos para la historia monetaria de España, Madrid, 1843, pp. 19-21, y en Aloïs Heiss, Descripción general de las monedas hispano-cristianas desde la invasión 
de los árabes, Madrid, 1865, tomo I, doc. IX, p. 291. Completo en Julio Torres, El Ordenamiento de Cuenca, "Nvmisma" 238 (1996), pp. 132-139.

Aranda 1461: Archivo Municipal de Murcia, Cartulario real 1453-1478, ff. 120r-124v. Editado en María C. Molina Grande, Documentos de Enrique IV, Colección de documentos para la Historia del Reino de Murcia XVIII, Murcia, 1988, doc. 149 , pp. 349-365.

Madrid 1462: Archivo del Ayuntamiento de Burgos, Sección Histórica, no 1315. Editado en Félix-Ángel Sainz Varona, La moneda de vellón de Enrique IV. La Ordenanza de 1462, "Boletín Corporativo de la Academia Burgense" 199 (1982), pp. 231-265.

Segovia 1471: Archivo General de Simancas, Diversos de Castilla 1, 52 (1 ${ }^{a}$ hoja) y AGS, DC 4, 27 (hojas 2 a 11). Ediciones: Cortes de los antiguos reinos de León y Castilla, Real Academia de la Historia, tomo tercero, pp. 812 y ss., Madrid 1866 y Memorias de don Enrique IV de Castilla, tomo II, colección diplomática, Madrid, 1835-1913.

Medina 1497: Quaderno de Ordenanças de la lauor de la moneda. 1497 junio 13. Editada en Libro en que están copiladas algunas bullas de nuestro muy sancto Padre concedidas en fauor de la jurisdicción real de sus altezas e todas las pragmáticas que están fechas para la buena gouernación del reyno..., [Alcalá de Henares], ff. CXCVII b ss. y en las recopilaciones posteriores.

\subsection{Relación cronológica de algunas fuentes valencianas, con indica- ción de su edición impresa}

Valencia 1308: Archivo de la Corona de Aragón, Reg. 231, ff. 31 y ss. Editado en Joaquim Botet i Sisó: Les monedes catalanes, tomo III, Barcelona, 1911, doc. XVIII, p. 283.

Valencia 1417: Archivo del Reino de Valencia, Títulos y enajenaciones, vol. II, ff. 228-230. Editado en Felipe Mateu y Llopis, El vocabulari medieval de l'exercici de la monederia segons documents valencians, "Butlletí de Dialectologia Catalana" 24 (1936), pp. 98-126, doc. I, p. 112.

Valencia 1417b: Archivo del Reino de Valencia, Títulos y enajenaciones, vol. II, ff. $176 v$ y ss. Editado en F. Mateu, El vocabulari, doc. III, p. 118.

Valencia 1459: Archivo del Reino de Valencia, Batllia, Contractes, any 1459, ff. 16091613. Editado en F. Mateu, El vocabulari, doc. IV, p. 120.

Valencia 1465: Archivo del Reino de Valencia, Batllia, Contractes, any 1465, ff. 302 y ss. Editado en F. Mateu, El vocabulari, doc. V, p. 124.

\subsection{Obras impresas de interés no citadas en el texto}

Bompaire, Marc, Lieux de monnaie et ateliers monétaires dans la France médiévale, en I luoghi della moneta. Le sedi delle zecche dall'antichità all'età moderna (Milano 22-23 de octubre 1999), Milán, 2001.

Botet i Sisó, Joaquim, Les monedes catalanes, Barcelona, 1908-1911, 3 vols.

Libro en que están copiladas algunas bullas de nuestro muy sancto Padre concedidas en fauor de la jurisdicción real de sus altezas e todas las pragmáticas que están fechas para la buena gouernación del reyno..., [Alcalá de Henares], 1503.

Cabañas, María Dolores, Notas sobre los monederos de Cuenca en el siglo XV, "En la España medieval" II (1982), pp. 183-205.

Challis, Christopher E., Assays and assaying in the reigns of Henry III and Edward I, en Mayhew, N.J., Spufford, P. (eds.), Later Medieval Mints. Organisation, Administration and Techniques, Oxford, 1988, pp. 76-86. 
Cooper, Denis R., The art and craft of coinmaking. A history of minting technology, London, 1988.

Finetti, Angelo, Dalla coniazione manuale all'introduzione del bilanciere, en Gonzaga, I,. Moneta. Arte. Storia, Mantova, 1995, pp. 36-53.

I luoghi della moneta Le sedi delle zecche dall'antichità all'età moderna. Atti del convegno Internazionale, 22-23 de octubre 1999 Milano, Milán, Comune di Milano, 2001.

Lazo García, Carlos, Economía colonial y régimen monetario. Perú: siglos XVI-XIX, 3 vols., Lima 1992.

Mariño, Beatriz, Testimonios iconográficos de la acuñación de moneda en la Edad Media. La portada de Santiago de Carrión de los Condes, en Artistes, artisans et production artistique au Moyen Âge. Colloque international. CNRSUniversité de Rennes II (1983), vol. I, pp. 499-513, París, 1986.

McLees, Christopher, The late medieval mint workshops at the Archbishop's Palace, Trondheim, "Antiquity" 68 (1994), pp. 264-274.

McLees, Christopher, Itinerant craftsmen, permanent smithies and the archbishop's mint: the character and context of metalworking in medieval Trondheim, "Historical Metallurgy" 30/2 (1996), pp. 121-135.

Metcalf, David Michael; Merrick, J.M., Studies in composition of early medieval coins, "The Numismatic Chronicle". Seventh series, volume VII (1967), pp. 167-181.

Pérez García, María Pilar, La fabricación de moneda en la ceca palentina: siglo XV, en II Congreso de Historia de Palencia, Palencia, 1989, vol. 2, pp. 601-608.

Pérez García, María Pilar, La Real Fábrica de Moneda de Valladolid a través de sus registros contables. Siglos XV-XVIII, Valladolid, 1990.

Pineda Aguilar, Agustín, La época de la gestión delegada 1535-1732, en Las casas de moneda en los Reinos de Indias, tomo II, Cecas de fundación temprana, Madrid, 1997.

Risvaag, Jon Anders, Mints in Scandinavia: the case of Trondheim, en I luoghi della moneta. Le sedi delle zecche dall'antichità all'età moderna (Milano 22-23 de octubre 1999), Milán, 2001, pp. 131-140.

Sainz Varona, Félix-Ángel, La moneda de vellón de Enrique IV. La Ordenanza de 1462, "Boletín Corporativo de la Academia Burgense" 199 (1982), pp. 231-265.

Sellwood, David, Alterations in mint technology for the edwardian penny, en Metcalf, D.M., Oddy, W.A. (eds.), Metallurgy in Numismatics, I, Londres, 1980, pp. 178-179.

Spufford, Peter, Mint organisation in late medieval Europe, en Mayhew, Nicholas J., Spufford, Peter (eds.), Later Medieval Mints. Organisation, Administration and Techniques, Oxford, 1988, pp. 7-29.

Spufford, Peter, Dinero y moneda en la Europa medieval, Barcelona, 1991.

Stahl, Alan, The Mint of Venice in the thirteenth century, en Mayhew, Nicholas J., Spufford, Peter, eds., Later Medieval Mints. Organisation, Administration and Techniques, Oxford, 1988, pp. 97-127.

Stahl, Alan, Zecca. The mint of Venice in the Middle Ages, Baltimore \& London-New York, 2000.

Torres, Julio, El Ordenamiento de Cuenca, "Nvmisma” 238 (1996), pp. 123-146.

Torres, Julio, El procés de fabricació de la moneda medieval, en Mediae Aetatis Moneta. La moneda a la Mediterrània medieval, Barcelona, 2006, pp. 61-64 (versión castellana El proceso de fabricación de la moneda medieval en pp. 185-187, versión inglesa The process of producing medieval coinage en pp. 233-234).

Torres, Julio, Evolución histórica de la fabricación de moneda, en La moneda en Navarra, Pamplona, 2001, pp. 257-286. 
Torres, Julio, La gallina de los huevos de cobre, “Gaceta Numismática” 161 (2006), pp. 5-22.

Travaini, Lucia, Mint organisation in Italy between the twelfth and fourteenth centuries: a survey, en Mayhew, Nicholas J., Spufford, Peter (eds.), Later Medieval Mints. Organisation, Administration and Techniques, Oxford, 1988, pp. 39-60.

\section{BIBLIOGRAFÍA CITADA}

Arfe y Villafañe, Juan de, Quilatador de la plata, oro y piedras, Valladolid, 1572.

Arles, Adrien, Entre monnayage officiel et faux-monnayage: La fabrication de la monnaie au marteau en France (XIII - XVII siècles): Approche physicochimique, expérimentale et historique, tesis doctoral leída en la Universidad de Orléans, 2009.

http://tel.archives-ouvertes.fr/docs/00/45/52/41/PDF/2099ORLE1101_0_1. pdf [consulta: 30/11/2011].

Barrage, Fawzan (tr.), Chapter five of Al-Dawhat al-Mushtabakat fi dawabit dar alsikka by Abi al-Hasan 'Ali b. Yusuf al-Hakim, "As-Sikka: The on line journal of the Islamic Coins Group" 3/1 (2001).

Belaubre, Jean, Monnaies médievales. 2. L'ère du gros (Les collections monétaires, Administration des Monnaies et Médailles), París, 1988.

Ben Romdhane, Khaled, Traité inédit de technique monétaire, "Revue Numismatique", VI série, XXX (1988), pp. 207-226.

Bompaire, Marc; Dumas Françoise, Numismatique médiévale, Turnhout, 2000.

Bouyon, Bernard, Ainsi frappait-on les monnaies au Moyen-Age, "Monnaies" 7 (1992).

Bouyon, Bernard, Études de gravure monétaire. De l'Italie grecque archaïque à l'Europe du $17^{e}$ siècle, Wetteren, 1998.

Bouyon, Bernard, Outillages monétaires de Charles VIII en Monnaies médievales, vol. 2. L'ère du gros, (Les collections monétaires, Administration des Monnaies et Médailles), París, 1988.

Caunedo del Potro, Betsabé; Córdoba de la Llave, Ricardo, El arte del alguarismo, Salamanca, 2000.

Céspedes del Castillo, Guillermo, Las cecas indianas en 1536-1825, vol. I de Las casas de moneda en los reinos de Indias, Madrid, 1996.

Craig, John, The Mint. A History of the London Mint from A.D. 287 to 1948, Cambridge, 1953.

Cahen, Claude, La frappe des monnaies en Égypte au VI'/XII' siècle d'après le Minhāj d'Al-Makhzümï, en Dickran K. Kouymjian (ed.), Near Eastern Numismatics, Iconography, Epigraphy and History. Studies in honor of George C. Miles, Beirut, 1974.

Córdoba de la Llave, Ricardo, Cálculo, técnica y moneda. Un manual castellano de ensayadores y maestros de moneda del siglo XIV, en Caunedo, B., Córdoba, R. (eds.), El arte del alguarismo, pp. 83-128.

Córdoba de la Llave, Ricardo, Ciencia y técnica monetarias en la España bajomedieval, Madrid, 2009.

Dumas-Dubourg, Françoise, Le monnayage des Ducs de Bourgogne, Louvain, 1988.

Ehrenkreutz, Andrew S., Contributions to the knowledge of the fiscal administration of Egypt in the Middle Ages, "Bulletin of the School of Oriental and African Studies" 16 (Londres, 1954), pp. 502-514. 
Ehrenkreutz, Andrew. S., Extracts from the Technical Manual on the Ayyubid Mint in Cairo, "Bulletin of the School of Oriental and African Studies" 15 (Londres, 1953), pp. 423-447.

Ehrenkreutz, Andrew S., Monetary Change and Economic History in the Medieval Muslim World, Hampshire, 1992.

Estrada-Rius, Albert, Alcaldes de la Seca versus Cònsols de Mar: apunts sobre un conflicte de jurisdiccions, en Narbona, R. (coord.), La Mediterrània de la Corona d'Aragó, segles XIII-XVI\& VII Centenari de la Sentència Arbitral de Torrellas, 1304-2004: XVIII Congrés d'Història de la Corona d'Aragó, vol. I, Valencia, 2005, pp. 583-594.

Estrada-Rius, Albert, El capítol de la seca reial de Barcelona: notes a propòsit d'un llibre d'actes (1577-1581, "Estudis històrics i documents dels arxius de protocols" 22 (2004), pp. 77-94.

Estrada-Rius, Albert, Els col-legis d'obrers i de moneders en els territoris mediterranis de la Corona d'Aragó, en Mediae Aetatis Moneta. La moneda a la Mediterrània medieval, Barcelona, 2006, pp. 71-79.

Estrada-Rius, Albert, La ceca real de Barcelona en la Baja Edad Media. Notas para el estudio de su organización, en Actas XI Congreso Nacional de Numismática, Zaragoza, 2002.

Estrada-Rius, Albert, La ceca real de Barcelona. El "Col-legi de la Seca Reial de Barcelona". Notas para su estudio, "Ius fugit: Revista interdisciplinar de estudios histórico-jurídicos" 12 (2003), pp. 445-462.

García-Bellido, María Paz, Problemas técnicos de la fabricación de moneda en la Antigüedad, "Nvmisma" 174-176 (1982), pp. 9-50.

García Luján, José Antonio, Privilegios de los monederos de la ceca de Toledo, "Nvmisma" 150-155 (1978), pp. 541-555.

Gozalbes, Manuel; Ripollès, Pere Pau, La fabricación de moneda en la Antigüedad, en Actas XI Congreso Nacional de Numismática, Zaragoza, 2002. pp. 11-33. http://www.uv.es/ ripolles/Web_PP/Tema-3.htm [consulta: 30/11/2011].

Hackens, Tony, Terminologie et techniques de fabrication, en Numismatique antique. Problèmes et méthodes, Nancy-Louvain, 1975, pp. 1-15.

Ladero Quesada, Miguel Ángel, Fiscalidad y poder real en Castilla (1252-1369), Madrid, 1993.

Ladero Quesada, Miguel Ángel, La Hacienda Real de Castilla 1369-1504. Estudios y documentos, Madrid, 2009.

Ladero Quesada, Miguel Ángel, La política monetaria en la Corona de Castilla, 1369-1497, "En la España Medieval” 11 (1988), pp. 79-123.

Ladero Quesada, Miguel Ángel, Monedas y políticas monetarias en la Corona de Castilla (siglos XIII a XV), en Moneda y monedas en la Europa medieval ( siglos XII-XV), XXVI Semana de Estudios Medievales, Estella-Lizarra, 1923 de julio 1999, Pamplona, 2000, pp. 129-178.

Lazo García, Carlos; Torres Bohl, José; Arana Bustamante, Luis, La hornaza: taller colonial de acuñación de macuquinas, Lima, 1991.

Lluis y Navas, Jaime, Aspectos de la organización legal de la amonedación en la Edad Media castellana, "Nvmisma" 40-41 (1959), pp. 9-80.

Lluis y Navas, Jaime, La ordenación de la amonedación en la Corona de Aragón en el siglo XIII, "Nvmisma" 96-101 (1969), pp. 25-99.

Lluis y Navas, Jaime, La ordenación de la amonedación en la Corona de Aragón en el siglo XIV, "Nvmisma" 102-107 (1970), pp. 59-199.

Lluis y Navas, Jaime, La ordenación de la amonedación en la Corona de Aragón a fines de la Edad Media, "Nvmisma" 108-113 (1971), pp. 9-160. 
Lluis y Navas, Jaime, Los orígenes del derecho sobre amonedación en Cataluña y Aragón," Nvmisma" 48-53 (1961), pp. 27-99.

Lopez, Roberto S., Continuità e adattamento nel medio evo: un millennio di storia delle associazioni di monetieri nell'Europa meridionale, en Studi in onore di Gino Luzzatto,vol. II, Milán, 1949, pp. 74-117.

Lopez, Roberto S., I monetieri del primo medioevo. La più antica aristocrazia professionale laica che la storia ricordi, Milán, 1991.

Lopez, Roberto S., The shape of medieval monetary history, Londres, 1986.

MacKay, Angus, Moneda, precios y política en la Castilla del siglo XV, Granada, 2006.

Mateu y Llopis, Felipe, Acerca de la política monetaria de Fernando el Católico y en especial en el Reino de Valencia (1474-1515), Valencia, 1957.

Mateu y Llopis, Felipe, El vocabulari medieval de l'exercici de la monederia segons documents valencians, "Butlletí de Dialectologia Catalana" 24 (1936), pp. 98-126.

Mateu y Llopis, Felipe, Ensayo sobre una Casa Real de Moneda de uno de los Estados de la Corona de Aragón. La Ceca de Valencia y las acuñaciones valencianas de los siglos XIII al XVIII, Valencia, 1929.

Mateu y Llopis, Felipe, La técnica medieval de las acuñaciones monetarias, "Nvmisma" 1 (1951), pp. 69-74.

Mateu y Llopis, Felipe, Libre dels privilegis de la Seca y Casa Real de la Moneda de sa Magestat de la ciutat y regne de València los quals se han vertit de latí en romans en lo any de la nativitat del Senyor MDCXXX, transcripción y estudio preliminar de F. M. y L., Valencia, 1957.

Mateu y Llopis, Felipe, Notas y documentos para el estudio de la política monetaria de Juan I de Aragón y en especial en el reino de Valencia, en VIII Congreso de Historia de la Corona de Aragón, tomo II, vol. II, pp. 179-195 (apéndice documental), Valencia, 1970.

Mayhew, Nicholas J., From Regional to Central Minting, 1158-1464, capítulo 2 en Challis, C.E. (ed.), A new history of the Royal Mint, Cambridge, 1992, pp. 83-178.

Mayhew, Nicholas J.; Spufford, Peter (eds.), Later Medieval Mints. Organisation, Administration and Techniques, Oxford, 1988.

Mones, Hussain, 'Ali Ibn Yusuf Al-Hakin, Abu-l-Hasan, Al-dawha al-mustabika fi dawabit dar al-sikka, Edición crítica, Madrid, Instituto de Estudios Islámicos, 1960.

Peres, Damião, História dos moedeiros de Lisboa como classe privilegiada, 2 vol., Lisboa, 1964-1965.

Ripoll Roig, Maria Eugènia, La Seca o Casa de la Moneda de Barcelona dels precedents al segle XIX, Barcelona, 2008.

Roma Valdés, Antonio, Emisiones monetarias leonesas y castellanas de la Edad Media. Organización, economía, tipos y fuentes, [s.1.], 2010.

Roma Valdés, Antonio, Moneda y sistemas monetarios en Castilla y León durante la Edad Media (1087-1366), Barcelona-Madrid, 2000.

Roma Valdés, Antonio; Braña Pastor, José Luis, El vellón castellano del siglo XV, [s.1.], 2010.

Spufford, Peter, Mint organisation in the Burgundian Netherlands in the fifteenth century, en Studies in numismatic method presented to Philip Grierson, Cambridge, 1983, pp. 239-261.

Toll, Christopher, Minting technique according to Arabic literary sources, "Orientalia Suecana" 19-20 (1970-1971), pp. 125-139.

Toll, Christopher, The fabrication of Arabic coins, en Kenneth Jonsson \& Brita Malmer (eds.), Sigtuna Papers. Proceedings of the Sigtuna Symposium on Vi- 
king-Age Coinage 1-4 june 1989 (Commentationes de nummis saeculorum IX-XI in Suecia repertis. Nova series 6), Stockholm, 1990, pp. 331-333.

Torres, Julio, Acuñación de moneda. De los talleres ambulantes a las grandes factorías, en Ars Mechanichae, Madrid, 2008.

Torres, Julio, Alear, aleación, ley y otros términos conexos en la Romania medieval, "Revista de Lenguas y Literaturas Catalana, Gallega y Vasca" V (19961997), pp. 129-150.

http://e-spacio.uned.es/fez/eserv.php?pid=bibliuned:Llcgv-7646E7A0-6EC432CF-CC4F-C9E6BA25D508\&dsID=Alear.pdf [consulta: 30/11/2011].

Torres, Julio, España. Cecas medievales y modernas del Reino de Castilla. Un repaso bibliográfico, en I luoghi della moneta. Le sedi delle zecche dall'antichità all'età moderna. Atti del Convegno Internazionale. Milano 22-23 ottobre 1999, Milán, 2001.

Torres, Julio, La fabricación de la moneda en la Edad Media, en Actas XI Congreso Nacional de Numismática, Zaragoza, 2002.

Torres, Julio, Las cecas romanas y su personal, "Archivo Español de Arqueología" 76, (2003), pp. 131-152. http://aespa.revistas.csic.es/index.php/aespa/article/view/110/108 [consulta: 30/11/2011].

Torres, Julio, Monederos de piedra. Escenas de acuñación en el románico palentino, en Travaini, Lucia y Bolis, Alessia (eds.), Conii e scene di coniazione, Roma, 2007, pp. 301-326.

Torres, Julio, Moneta Caesaris. La ceca imperial de Roma, en XII Curs d'Història monetària d'Hispània: Els tallers monetaris: organització i producció, Barcelona, 2008, pp. 89-103.

Torres, Julio, Ordenanzas medievales sobre fabricación de moneda en Castilla. Edición y análisis del vocabulario técnico, 1998. http://eprints.ucm.es/tesis/19972000/H/3/H3074401.pdf [consulta: 30/11/2011].

Torres, Julio, Primeros acuñadores en Castilla y León, en X Congreso Nacional de Numismática (Albacete 1998), Madrid, 2002.

Travaini, Lucia, Zecca, en Enciclopedia dell'Arte Medievale, vol. XI, Roma, 2000, pp. 844-847.

Fecha de recepción del artículo: julio 2011

Fecha de aceptación y versión final: agosto 2011 